\title{
Kappa-opioid receptor signaling in the striatum as a potential modulator of dopamine transmission in cocaine dependence
}

\author{
Pierre Trifilieff ${ }^{1,2}$ and Diana Martinez ${ }^{1}{ }^{*}$ \\ ${ }^{1}$ New York State Psychiatric Institute, Columbia University, New York, NY, USA \\ ${ }^{2}$ NutriNeuro, UMR 1286 INRA, University Bordeaux 2, Bordeaux, France
}

Edited by:

Nicholas W. Gilpin, Louisiana State University Health Sciences Center New Orleans, USA

Reviewed by:

Raj Sevak, University of California Los Angeles, USA

Luigi Janiri, Università Cattolica del S. Cuore, Italy

*Correspondence:

Diana Martinez, New York State

Psychiatric Institute, Columbia

University, 1051 Riverside Drive \#32,

New York, NY 10032, USA

e-mail:dm437@columbia.edu
Cocaine addiction is accompanied by a decrease in striatal dopamine signaling, measured as a decrease in dopamine D2 receptor binding as well as blunted dopamine release in the striatum. These alterations in dopamine transmission have clinical relevance, and have been shown to correlate with cocaine-seeking behavior and response to treatment for cocaine dependence. However, the mechanisms contributing to the hypodopaminergic state in cocaine addiction remain unknown. Here we review the positron emission tomography (PET) imaging studies showing alterations in D2 receptor binding potential and dopamine transmission in cocaine abusers and their significance in cocaine-seeking behavior. Based on animal and human studies, we propose that the kappa receptor/dynorphin system, because of its impact on dopamine transmission and upregulation following cocaine exposure, could contribute to the hypodopaminergic state reported in cocaine addiction, and could thus be a relevant target for treatment development.

Keywords: imaging, kappa opioid receptor, dopamine, cocaine dependence, striatum, dopamine receptor

\section{INTRODUCTION}

Studies imaging the neurochemistry associated with cocaine addiction in humans have largely focused on dopamine signaling in the striatum. These studies show that pre-synaptic dopamine release, in response to the administration of a stimulant, is reduced in cocaine abusers compared to healthy controls. This has important implications for this disorder, since the reduction in dopamine release has been shown to correlate with increased cocaine-seeking behavior. Importantly, the imaging studies were performed at about 14 days abstinence, which has clinical relevance, since previous studies have shown that cocaine abusers who achieve 2 weeks of abstinence have a better treatment response compared to those who do not (Bisaga et al., 2010; Oliveto et al., 2012). Thus, a better understanding of the mechanisms behind blunted dopamine release would be expected to have implications for treatment development. Among the possible mechanisms that are known to regulate striatal dopamine release is dynorphin acting at the kappa receptor. Kappa receptor activation in the striatum has been shown to inhibit stimulant-induced dopamine release, in addition to striatal dopamine levels and dopamine neurons activity (for review, see Koob and Le Moal, 2008; Muschamp and Carlezon, 2013). Furthermore, studies in humans and animals show that dynorphin is significantly upregulated following chronic cocaine exposure, and that this effect is long lasting (for review, see Koob and Le Moal, 2008; Muschamp and Carlezon, 2013), which could account for the decrease in dopamine signaling seen after 2 weeks of abstinence in the human imaging studies. Here, we review the data suggesting that the cocaine-induced elevation in dynorphin may contribute to the hypodopaminergic state observed in cocaine addiction.

\section{PET IMAGING OF DOPAMINE TRANSMISSION IN COCAINE} ADDICTION

\section{PRINCIPLES OF PET IMAGING}

Positron emission tomography (PET) allows imaging of the neurochemistry associated with drug and alcohol addiction in the human brain. This imaging modality uses radionuclide-labeled ligands that bind to a specific receptor, and the radioligands used most frequently in addiction research label the dopamine receptors. Radiotracers that label the dopamine type 2 family of receptors (referred to as D2) can also be used to measure changes in extracellular dopamine. This is performed by imaging with radiotracers that are sensitive to changes in extracellular dopamine, and obtaining scans before and after the administration of a psychostimulant (such as amphetamine or methylphenidate). These stimulants increase extracellular dopamine levels, which results in a reduction of dopamine receptors that are available to bind to the radiotracer, shown in Figure 1. For reasons that are not completely understood, this method can be used with most D2 receptor radiotracers but not with radiotracers that bind to the D1 receptor. Thus, imaging studies using the $\mathrm{D} 2$ receptor radiotracers (such as [11C]raclopride or [18F] fallypride) can be used to measure changes in endogenous dopamine, whereas radiotracers that label the D1 receptor (such as [11C]NNC112 or [11C]SCH23390) cannot (Abi-Dargham et al., 1999; Chou et al., 1999; Laruelle, 2000; Martinez and Narendran, 2010).

The main outcome measure in radioligand imaging studies is receptor binding to the radiotracer, referred to as BPND, defined as the ratio of specific to non-specific binding (Innis et al., 2007). The change in extracellular dopamine resulting from stimulant 


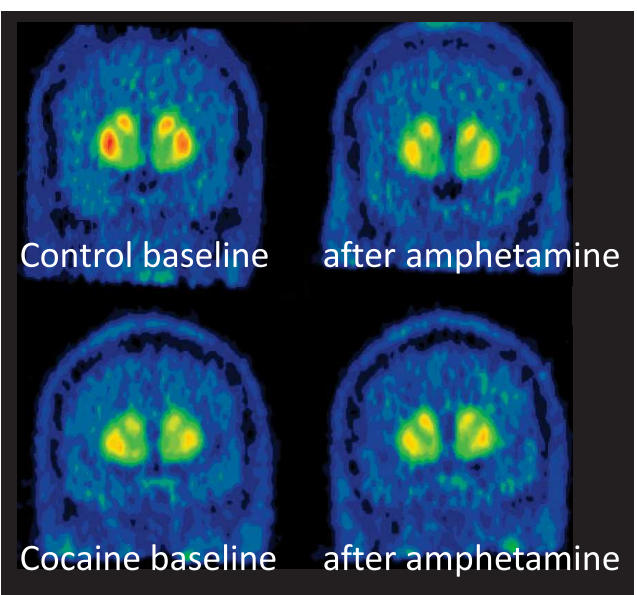

FIGURE 1 | PET scans in a healthy control and cocaine-dependent subject. The comparison of the top panels (pre- and post-amphetamine administration) in the healthy control shows that radiotracer

([11C]raclopride) binding is reduced in the striatum following amphetamine. The cocaine-dependent subject (bottom panel) has have lower D2 receptors compared the control in the baseline condition. In addition, the cocaine abuses has less radiotracer displacement ( $\triangle$ BPND) following amphetamine. Adapted from Trifilieff and Martinez "Cocaine: Mechanism and Effects in the Brain" in "The Effects of Drug Abuse on the Human Nervous System" M. Kuhar and B. Madras editors, 2012, publisher Neuroscience-Net, LLC.

administration is measured by comparing baseline BPND (prestimulant administration) and BPND following the stimulant. This is used to derive the percent change in BPND, or $\triangle B P N D$, defined as [(BPNDbaseline - BPNDchallenge)/BPNDbaseline]. Previous studies in non-human primates have shown that $\triangle \mathrm{BPND}$ correlates linearly with changes in extracellular dopamine, measured with microdialysis (Breier et al., 1997; Endres et al., 1997; Laruelle et al., 1997). Thus, $\triangle B P N D$ provides an indirect measure of stimulant-induced pre-synaptic dopamine release, and can be used to characterize the alterations in dopamine signaling that occur in cocaine dependence.

\section{PET IMAGING OF DOPAMINE RECEPTORS IN COCAINE ADDICTION}

To date, six studies have been performed imaging the D2 receptor in cocaine abusers, and these consistently show a decrease in binding in the striatum compared to matched controls (Volkow et al., 1990, 1993, 1997; Martinez et al., 2004, 2009a, 2011). The decrease is about $15-20 \%$ and occurs in both the ventral and dorsal striatum. Importantly, animals with low D2 receptor levels in the striatum, prior to drug exposure, display greater cocaine selfadministration (Morgan et al., 2002; Czoty et al., 2004; Nader et al., 2006; Dalley et al., 2007). Imaging studies in humans show that low striatal D2 receptor binding in cocaine abusers in the striatum correlates with decreases in glucose metabolism in the orbito-frontal cortex and cingulate gyrus, which process drive and affect, and may lead to continued drug-taking behavior (Volkow et al., 1993, 1999). Several authors have proposed that changes in D2 receptor binding in addiction could reflect behavioral vulnerability to drug self-administration, such as lack of cognitive control or increased impulsivity (Everitt et al., 2008; Dalley et al., 2011; Groman and Jentsch, 2012).

One PET imaging study has measured D1 receptor binding in cocaine abuse (Martinez et al., 2009b). This study showed no difference in D1 receptor binding in cocaine abusers compared to controls, which is consistent with a post-mortem study of striatal D1 receptor mRNA (Meador-Woodruff et al., 1993). However, the imaging study also showed that, within the cocaine-dependent subjects, low D1 receptor binding in the ventral striatum was associated with greater choices to self-administer cocaine. Thus, this finding may represent a phenotype in which low D1 receptor binding in the limbic striatum is associated with a greater vulnerability to the reinforcing effects of cocaine. This is in agreement with pharmacologic studies in humans showing that stimulation of D1 receptors reduces, whereas blockade of the D1 receptor enhances, the reinforcing effects of cocaine (Haney et al., 1999, 2001). Taken together, these studies indicate that decreased signaling at the D1 receptor may be associated with more cocaine-taking behavior.

\section{PET IMAGING DOPAMINE RELEASE IN COCAINE ABUSERS}

Imaging studies measuring pre-synaptic dopamine release show that cocaine dependence is associated with a reduction in responsiveness of the dopamine system to a stimulant challenge. For example, in healthy human volunteers, the administration of a psychostimulant produces a decrease in [11C]raclopride binding ( $\triangle \mathrm{BPND}$ ) of 15-20\% (Volkow et al., 1994; Drevets et al., 2001; Martinez et al., 2003; Munro et al., 2006), but in cocaine abusers the decrease in [11C] raclopride binding is significantly blunted (Volkow et al., 1997; Malison et al., 1999; Martinez et al., 2007b, 2011). Thus, four studies have shown that cocaine dependence is associated with reduced [11C]raclopride displacement following stimulant administration compared to healthy controls, which represents a reduction in pre-synaptic dopamine release. PET imaging studies also show that cocaine abuse is associated with both decreased [18F]DOPA uptake and striatal vesicular monoamine transporter 2 binding, which provide measures of pre-synaptic dopamine stores (Wu et al., 1997; Narendran et al., 2012).

In addition to a reduction in stimulant-induced dopamine release, PET imaging has also shown that dopamine levels in the resting condition (without any stimulant administration) are reduced in cocaine dependence. This is performed by imaging the D2 receptors before and after acute depletion of endogenous dopamine using alpha-methyl-para-tyrosine (AMPT). Thus, imaging after AMPT administration results in an increase in [11C]raclopride binding, as opposed to the decrease seen after stimulant administration (Martinez et al., 2009a). AMPT administration resulted in an increase of $11.1 \pm 4.4 \%$ in [11C]raclopride binding in the striatum for healthy controls, but only $5.7 \pm 5.9 \%$ for cocaine-dependent volunteers (Martinez et al., 2009a), indicating that basal dopamine levels are decreased in cocaine abuse.

Taken together, imaging studies in cocaine abuse consistently show a reduction in striatal dopamine transmission, compared to healthy controls, measured as decreased pre-synaptic dopamine release (Volkow et al., 1997; Malison et al., 1999; Martinez et al., 2007b, 2011) and reduced baseline levels of endogenous dopamine (Martinez et al., 2009a). Similar findings have been shown in 
rodents (Parsons et al., 1991; Robertson et al., 1991; Rossetti et al., 1992; Weiss et al., 1992; Gerrits et al., 2002) and non-human primates (Castner et al., 2000; Kirkland Henry et al., 2009). Thus, cocaine dependence is associated with a hypodopaminergic state, which correlates with behaviors that contribute to addiction and relapse (Melis et al., 2005). Importantly, the PET scans showing blunted dopamine release were obtained after about 2 weeks of abstinence, to avoid the acute effect of cocaine on dopamine signaling, and due to the clinical relevance of this time point. Previous studies have shown that cocaine abusers who can achieve 2 weeks of abstinence have a better treatment response compared to those who do not (Bisaga et al., 2010; Oliveto et al., 2012).

\section{SIGNIFICANCE OF THE HYPODOPAMINERGIC STATE IN COCAINE ABUSE}

The impact of dopamine transmission on addiction has been demonstrated for decades, but its actual role in mediating the reinforcing effects of drugs of abuse remains under debate. Dopamine does not appear to only signal "reward" (drug or natural rewards), although dopamine neurons fire in response to the receipt of a reward, and during the expectation of a reward. However, dopamine signaling more likely mediates the reinforcing effects of natural rewards and abused drugs, and makes the behavior required to obtain the reward more likely to be repeated (Schultz, 2006; Berridge, 2007; Wise, 2008; Salamone and Correa, 2012). However, the imaging studies in cocaine dependence consistently show that pre-synaptic dopamine is reduced compared to controls, indicating that this disorder is associated with a hypodopaminergic state. This plays a crucial role in drug-seeking and taking, even after prolonged drug-free periods (Melis et al., 2005).

The imaging studies in human cocaine abusers show that blunted dopamine release correlates with an increase in cocaine self-administration (Martinez et al., 2007b, 2011). These studies showed that low dopamine release in cocaine abusers, measured as $\triangle \mathrm{BPND}$, was associated with the decision to take cocaine in the presence of competing non-drug reinforcers. The inability of the cocaine-dependent subjects with low dopamine release to alter their behavior can be viewed as an inability to respond to alternative sources of reward. This is consistent with the theory that decreased dopamine function in addiction results in a decreased interest to non-drug-related stimuli and increased susceptibility to the drug of choice (Melis et al., 2005).

These studies raise the question regarding the mechanism behind this decrease in pre-synaptic dopamine release. Previous studies in animals have shown that cocaine exposure results in reduced burst firing of the dopamine neurons of the ventral tegmental area (Brodie and Dunwiddie, 1990; Lacey et al., 1990; Ackerman and White, 1992; Gao et al., 1998). Decreases in extracellular dopamine levels in the nucleus accumbens have also been reported following cocaine withdrawal (Parsons et al., 1991; Robertson et al., 1991; Rossetti et al., 1992; Weiss et al., 1992). Cocaine administration has also been shown to alter the sensitivity of D2 autoreceptors of the midbrain (Gao et al., 1998; Lee et al., 1999; Marinelli et al., 2003), which could reduce presynaptic dopamine release. In addition to these functional changes in dopamine signaling, animal studies have also shown that cocaine exposure produces morphological changes in dopamine neurons. These include alterations in dendritic spine density and morphology and a reduction in the size of the dopamine neurons of the ventral tegmental area (Melis et al., 2005).

Presently, it is unknown whether these changes occur in the human brain. Human studies of the dopamine transporter (DAT), which can serve as a marker for the integrity of the dopamine neurons (Fusar-Poli and Meyer-Lindenberg, 2013), show that the DAT is increased in post-mortem studies of cocaine abusers (Little et al., 1993, 1999). However, imaging studies show that the DAT is increased for a short time period following the cessation of cocaine use, but soon return to control levels (Volkow et al., 1996; Wang et al., 1997; Malison et al., 1998). But measuring DAT binding alone is unlikely to reveal morphological alterations of the dopamine neurons, and other means for investigating this with imaging in humans are not yet available. With respect to the dopamine receptors in the midbrain, one study in methamphetamine abusers and another in cocaine abusers showed that D3 receptor binding is elevated in the substantia nigra/ventral tegmental area (SN/VTA) compared to controls (Matuskey et al., 2011; Boileau et al., 2012). The specific role of the D3 receptor in the modulation of dopamine transmission and its function as an autoreceptor are still highly debated (Sokoloff et al., 2006). However, considering the possible implication of this receptor in modulating dopamine synthesis and release (for review, Gross and Drescher, 2012), an increase in D3 receptor levels in SN/VTA may contribute to the hypodopaminergic state observed in addiction.

In addition to alterations in the dopamine neurons themselves, it is possible that other neurotransmitter systems may be regulating the dopamine system. Candidates include the glutamatergic, GABAergic, serotoninergic, or noradrenergic afferents to the dopamine and striatal neurons, which have been reviewed previously (Melis et al., 2005; Gerfen and Surmeier, 2011). In this review, we focus on the kappa/dynorphin system as a potential modulator of dopamine release in cocaine abuse for the following reasons: (1) among the neurotransmitters that modulate dopamine transmission, evidence from human and animal studies show that cocaine exposure significantly upregulates kappa/dynorphin signaling (for review, see Wee and Koob, 2010; Muschamp and Carlezon, 2013); (2) in the striatum, dynorphin signaling strongly regulates dopamine signaling and animal studies show that activation of the kappa system reduces pre-synaptic dopamine release (Koob and Le Moal, 2008; Muschamp and Carlezon, 2013). Thus, elevated striatal dynorphin activity at the kappa receptor could be a compensatory adaptation that inhibits psychostimulant-induced dopamine release (Koob and Le Moal, 2008; Muschamp and Carlezon, 2013).

\section{DYNORPHIN AND KAPPA RECEPTORS}

\section{KAPPA RECEPTOR/DYNORPHIN SIGNALING}

Dynorphin (DYN) is the class of peptides cleaved from prodynorphin, which include dynorphin A and B (and others) which have a high affinity for the kappa receptor (KOR) (Chen et al., 2007). Currently, only one KOR subtype (type 1) has been cloned, and while types 2 and 3 have been hypothesized, they have yet to be fully characterized (Shippenberg et al., 2007). KOR selective agonists and antagonists have been developed in recent years, allowing investigation into the neurochemical and behavioral effects of the 
DYN/KOR system. The KOR agonists include the arylacetamides U69593 and U50488, and salvinorin A, a naturally occurring alkaloid found in the plant Salvia divinorum (Von Voigtlander and Lewis, 1982; Lahti et al., 1985; Roth et al., 2002). The selective KOR antagonists include nor-binaltorphimine (nor-BNI), 5'-guanidinonaltrindole (GNTI), and JDTic (Endoh et al., 1992; Jones and Portoghese, 2000; Carroll et al., 2004). Activation of the KOR is aversive in both humans and animals, and KOR agonists are not self-administered by animals (Mucha and Herz, 1985; Tang and Collins, 1985; Pfeiffer et al., 1986; Bals-Kubik et al., 1993; Walsh et al., 2001; Wadenberg, 2003), although the same cannot be said of some humans.

KOR signaling is complex and agonists have been shown to activate, inhibit and/or have no effect on downstream signaling (i.e., cAMP, IP3/DAG, and $\mathrm{Ca}^{2+}$ ) depending on experimental conditions (Tejeda et al., 2012). It is likely that KOR agonists display inverted $U$-shape effects, because of KOR ability to recruit both inhibitory $\mathrm{G} \beta \gamma, \mathrm{G} \alpha_{\mathrm{i}}, \mathrm{G} \alpha_{\mathrm{o}}, \mathrm{G} \alpha_{\mathrm{z}}$, and $\mathrm{G} \alpha_{16}$, and stimulatory, $\mathrm{G} \alpha_{s}$, G-proteins (Law et al., 2000; Tejeda et al., 2012). Nanomolar ligand concentrations result in the recruitment of inhibitory G-proteins and a decrease in membrane excitability as well as transmitter release via stimulation of $\mathrm{K}^{+}$-channel activity (Grudt and Williams, 1993) and inhibition of $\mathrm{Ca}^{2+}$-channel and presynaptic release machinery activity (Gross et al., 1990; Iremonger and Bains, 2009). In contrast, sub-nanomolar ligand concentrations may result in coupling of KOR to Gas and produce opposite effects (Crain and Shen, 1996; Tejeda et al., 2012). It should be noted that KOR activity can modulate D2 autoreceptor-dependent decrease in dopamine release by signaling interaction (Jackisch et al., 1994; Acri et al., 2001; Fuentealba et al., 2006).

\section{KAPPA RECEPTOR/DYNORPHIN IN DIRECT AND INDIRECT PATHWAYS OF THE STRIATUM}

The medium spiny neurons (MSNs) can be categorized into at least two subgroups according to their projections sites and the proteins they express (Gerfen, 2000; Gerfen and Surmeier, 2011). The "direct" or striatonigral pathway made up of MSNs that project monosynaptically to the medial globus pallidus and back to the dopamine neuron cell bodies of the substantia nigra. MSNs from the direct pathway express the dopaminergic D1 receptor, M4 muscarinic acetylcholine receptor, substance $\mathrm{P}$, and dynorphin. The indirect striatopallidal pathway is composed of MSNs that project to the lateral globus pallidus, which reach the substantia nigra through synaptic relays through the lateral globus pallidus and subthalamic nucleus. These MSNs express the dopaminergic D2 receptor, adenosine receptors and enkephalin. It should be noted that the segregation of these two populations of MSNs has been established in the dorsal striatum, but that several studies show that a subpopulation of MSNs in the NAc seem to co-express D1 and D2 receptors (George and O'Dowd, 2007; Valjent et al., 2009). Dopamine can activate or inhibit cyclic AMP-dependent signaling through D1 receptor and D2 receptor respectively, as we will review below. Therefore, dopamine is likely to have differential effects on D1- and D2-expressing MSNs and recent data suggest that, cocaine administration activate signaling pathways in D1-expressing, but actively inhibits them in D2-expressing MSNs (McClung et al., 2004; Bateup et al., 2010), which could account for the imbalance between direct and indirect pathways in addiction (Lobo et al., 2010; Pascoli et al., 2012).

D1 receptors recruit adenylyl cyclase through activation of the stimulatory $\mathrm{G} \alpha$ s protein and consequently stimulate the production of adenosine $3^{\prime}, 5^{\prime}$-monophosphate (cAMP) which leads to the activation of protein kinase A (PKA)-dependent signaling pathways. In contrast, D2 receptor inhibits adenylyl cyclase and cAMP/PKA pathways by recruiting inhibitory $\mathrm{G} \alpha_{i}$. Accordingly, cocaine activates PKA signaling pathway mainly through activation of D1 receptor and manipulation of this pathway alters behavioral responses to cocaine (Girault, 2012). One of the downstream targets of PKA is the transcription factor CREB. Interestingly, whereas overexpression of CREB in the nucleus accumbens reduces the rewarding properties of cocaine, overexpression of a dominant-negative form enhances it (Carlezon et al., 1998; Walters and Blendy, 2001; McClung and Nestler, 2008) suggesting that activation of CREB could counteract the postsynaptic effects of cocaine and therefore decrease behavioral response to cocaine. One of the downstream genes regulated by CREB in the nucleus accumbens encodes preprodynorphin, the precursor gene product of dynorphin (McClung and Nestler, 2008). Activation of the kappa receptor decreases cocaine-induced dopamine release (for review, see Wee and Koob, 2010; Muschamp and Carlezon, 2013). Accordingly, stimulation of the D1 receptor elevates dynorphin expression, which can be blocked with receptor antagonists (Liu and Graybiel, 1998). Thus, it has been proposed that activation of the D1/PKA/CREB pathway could be counteracting the effects of cocaine through synthesis and release of dynorphin (for review, see Wee and Koob, 2010; Muschamp and Carlezon, 2013), shown in Figure 2.

\section{KAPPA RECEPTOR/DYNORPHIN AND DOPAMINE SIGNALING}

The DYN/KOR receptor system has been shown to play a significant role in regulating striatal dopamine transmission. DYN immunoreactive axon terminals originating from D1 receptorexpressing MSNs are found in the caudate, putamen, and nucleus accumbens (Hurd and Herkenham, 1995; Van Bockstaele et al., 1995). The KOR is expressed both pre- and post-synaptically on dopamine neurons, and the pre-synaptic KOR is apposed to DAT on the dopamine axon terminals, indicating that this system closely regulates the mesoaccumbal dopamine neurons (Svingos et al., 2001).

A number of animal studies have shown that the administration of a KOR agonist reduces dopamine levels in the striatum and dopamine neuron activity in the nucleus accumbens and ventral tegmental area (Di Chiara and Imperato, 1988; Heijna et al., 1990, 1992; Donzanti et al., 1992; Spanagel et al., 1992; Maisonneuve et al., 1994; Xi et al., 1998; Thompson et al., 2000; Margolis et al., 2003; Zhang et al., 2004b). In fact, KOR activation reduces basal dopamine levels as well as stimulant-induced dopamine release (cocaine) (Spanagel et al., 1990; Maisonneuve et al., 1994; Carlezon et al., 2006; Gehrke et al., 2008). Reverse dialysis into the nucleus accumbens reduces extracellular dopamine (Donzanti et al., 1992; Zhang et al., 2004a). Notably, this effect is seen when the KOR agonist is administered into the striatum, whereas administration into the VTA appears to be species dependent (Spanagel et al., 1992; Chefer et al., 2005; Ford et al., 2006; Margolis et al., 2006). 


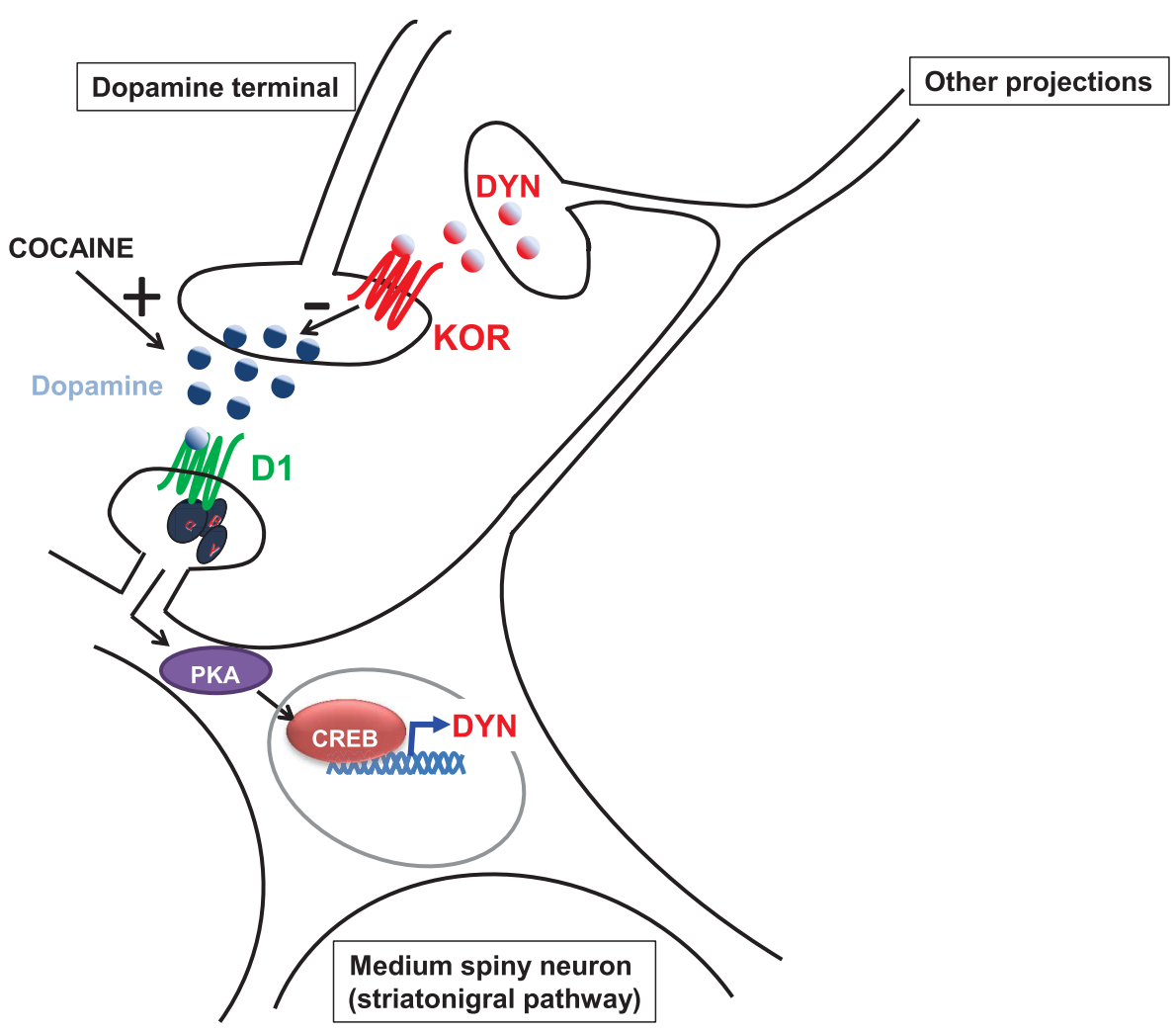

FIGURE 2 | Model by which the dynorphin/kappa system could counteract cocaine-induced dopamine release. Cocaine

administration elevates dopamine levels. Binding of dopamine on the D1 receptor expressed by medium spiny neurons from the striatonigral pathway (direct pathway) activates the cAMP/PKA/CREB pathway which leads to dynorphin (DYN) synthesis. Binding of DYN on kappa receptors (KOR) located on dopamine terminals exert an inhibitory effect on dopamine release.
KOR activation has been shown to inhibit electrically evoked $\left[{ }^{3} \mathrm{H}\right]$ dopamine release in the nucleus accumbens (Heijna et al., 1992; Yokoo et al., 1992), which also shows that activation of this receptor reduces striatal dopamine transmission. More recently, Chefer et al. (2005) showed that the deletion of KOR is associated with an enhancement of basal dopamine release. Alternatively, KOR antagonists stimulate the release of dopamine in the striatum (Maisonneuve et al., 1994; You et al., 1999; Beardsley et al., 2005). Lastly, repeated KOR agonist administration reduces striatal D2 receptor density (Izenwasser et al., 1998). These findings show that DYN/KOR signaling exerts inhibitory control over dopamine release and dopamine receptor signaling in the striatum (Bruijnzeel, 2009; Wee and Koob, 2010) and demonstrate that excessive KOR activation significantly reduces striatal dopamine transmission, independent of the modality used to measure dopamine transmission.

Notably, imaging studies show that, in addition to cocaine dependence, addiction to other substances of abuse also results in blunted pre-synaptic dopamine release, measured with PET. This finding has also been reported in studies of alcohol, methamphetamine, opiate, and tobacco dependence (Martinez et al., 2007a, 2012; Busto et al., 2009; Wang et al., 2012). While some studies have shown that the DYN/KOR system plays a role in these disorders as well (for review, see Wee and Koob, 2010; Koob, 2013), the effect of drug exposure on KOR and DYN is less clear and may even be down-regulated in methamphetamine and opiate dependence (Drakenberg et al., 2006; Frankel et al., 2007). Further studies are needed to clarify the interaction between the DYN/KOR system and dopamine signaling in these disorders.

\section{KAPPA RECEPTOR/DYNORPHIN SYSTEM IN COCAINE ABUSE}

Three post-mortem studies have been performed investigating KOR binding in cocaine abuse. The first of these, by Hurd and Herkenham (1993), showed a twofold increase in KOR binding in the caudate, but not the putamen or ventral striatum, in cocaine-dependent subjects compared to control subjects. Mash and Staley (1999) used in vitro autoradiography and ligand binding to map KOR in the brains of cocaine abusers and showed a twofold increase in the anterior and ventral sectors of the caudate and putamen, and nucleus accumbens compared to controls. Similar results were reported by Staley et al. (1997) who used radiolabeling to measure the KOR and reported a significant increase in KOR in the caudate, putamen, and nucleus accumbens in cocaine exposed compared to control brain tissue. These studies demonstrate that cocaine abuse or dependence is associated with a significant upregulation of the KOR in the striatum. However, to date, no human in vivo imaging studies of the KOR have been published in cocaine abuse. While previous PET studies 
imaged the mu opioid receptor in cocaine dependence (Zubieta et al., 1996; Gorelick et al., 2008), PET imaging of the KOR has not been previously possible due to the lack of an appropriate radiotracer. Therefore, correlations with clinical outcomes, such as cocaine-seeking behavior could not be performed. In addition, these post-mortem studies did not measure markers of dopamine transmission (such as receptor density or dopamine levels), so that it remains unknown whether the increase in KOR signaling coincides with a reduction in dopamine signaling largely described in PET imaging studies. Measuring both KOR binding and dopamine transmission in the same individuals will require the development of new radiotracers for KOR.

\section{COCAINE ADMINISTRATION AND DYNORPHIN}

A number of animal studies have shown that repeated cocaine administration increases levels of DYN, prodynorphin mRNA, and preprodynorphin mRNA. The initial studies measured peptide levels and showed that chronic dosing of cocaine increased striatal dynorphin levels by 40-100\% (Sivam, 1989; Smiley et al., 1990). Further studies measuring prodynorphin and preprodynorphin mRNA, instead of peptide levels, have replicated these findings. Daunais et al. (Daunais et al., 1993, 1995; Daunais and McGinty, 1995, 1996) showed that cocaine self-administration increases preprodynorphin mRNA in the caudate/putamen by more than $100 \%$. Similar results have been reported in studies by other groups as well, where the administration of cocaine has been shown to increase preprodynorphin mRNA levels 50-100\% in the caudate/putamen of rats and mice (Yuferov et al., 2001; Zhou et al., 2002; Jenab et al., 2003; Schlussman et al., 2003, 2005; Zhang et al., 2013). Spangler et al. (1993, 1996) demonstrated that cocaine increased prodynorphin mRNA in the caudate/putamen by $40 \%$, and that these levels remained elevated for days. Overall, the above studies in rodents consistently report that cocaine administration increases DYN, prodynorphin, and preprodynorphin mRNA with levels ranging from about 40 to 100\%. Previous studies have shown that the levels of DYN peptide and prodynorphin/preprodynorphin mRNAs correlate with each other, suggesting that increases in mRNAs closely reflect increases in the peptide itself ( $\mathrm{Li}$ et al., 1988; Sivam, 1996).

These findings in rodents have been replicated in studies of rhesus monkeys and humans. Fagergren et al. (2003) performed a study in rhesus monkeys who self-administered cocaine and showed that prodynorphin mRNA levels were increased in the dorsolateral caudate (83\%), central caudate (34\%), and the dorsal putamen (194\%). In humans, Hurd and Herkenham (1993) first reported that cocaine abuse was associated with an increase in preprodynorphin mRNA in the putamen and caudate in a postmortem study of cocaine abusing subjects compared to control subjects. More recently, Frankel et al. (2008) measured DYN peptide levels in a post-mortem study of cocaine abusers and controls subjects, and reported a significant increase in DYN in the caudate and a trend toward a significant increase in the putamen compared to control subjects. A very large increase was seen in the ventral pallidum but no difference was seen in the thalamus, frontal, temporal, parietal, and occipital cortices. Taken together, these studies indicate that cocaine exposure increases striatal DYN signaling at the kappa receptor in rodents, non-human primates, and humans. Considering the effect of DYN on dopamine signaling, it is likely that the sustained increase in DYN levels by cocaine exposure participates to the hypodopaminergic state described in cocaine abusers.

Theses findings in human and animal studies suggest that treatments that target KOR signaling would modulate cocaine-seeking behavior. However, animal studies exploring the effect of KOR agonist or antagonist administration on cocaine self-administration are mixed (for review, see Wee and Koob, 2010; Butelman et al., 2012). Partly, this effect depends on the reinforcement schedule used, doses of drug administered, and timing of the effect, since changes in KOR/DYN have a slow onset (Wee et al., 2009; Knoll et al., 2011). Moreover, the DYN/KOR system appears to play a more significant role in mediating the aversive effects that occur with cocaine exposure.

\section{KAPPA RECEPTOR/DYNORPHIN AND STRESSED-INDUCED COCAINE-SEEKING BEHAVIOR}

Animal studies have investigated the relationship between KOR activation and stress-induced cocaine-seeking behavior. DYN is released in response to physical stress in the striatum, amygdala, and hippocampus (Shirayama et al., 2004; Land et al., 2008), and blockade of the KOR reduces the effects of stress on cocaineseeking behavior. McLaughlin et al. (2003) showed that swim stress and social defeat stress both significantly enhance conditioned place preference (CPP) for cocaine in mice. This effect was blocked by KOR antagonist administration and was not seen in prodynorphin knock-out mice (McLaughlin et al., 2003, 2006). In addition, the administration of a KOR agonist prior to cocaine conditioning was shown to be as effective as stress in potentiating subsequent cocaine-induced CPP (McLaughlin et al., 2006). Beardsley et al. (2005) showed that lever pressing for cocaine is reinstated in rodents following uncontrollable footshock, and that this effect is blocked by the administration of JDTic, a KOR antagonist. Along these same lines, Redila and Chavkin (2008) showed that intermittent foot shock, forced swim, and KOR agonist administration all reinstate cocaine CPP in mice. This effect was blocked with pre-treatment with the KOR antagonist norBNI, and did not occur in mice lacking either the KOR or prodynorphin. Carey et al. (2007) also showed that pre-treatment with a KOR antagonist blocked stress-induced reinstatement of cocaine CPP.

These studies show that signaling at the KOR plays a significant role in cocaine-seeking behavior following stress. Recent studies have also shown that DYN signaling and corticotropin releasing factor (CRF) function together to increase the negative reinforcing effects of cocaine (Koob et al., 2004). Land et al. (2008) used a phospho-selective antibody for the activated form of KOR and showed that both physical stress and CRF administration resulted in DYN-dependent activation of the KOR. Valdez et al. (2007) showed that, in monkeys, cocaine-seeking behavior is reinstated by the administration of a KOR agonist, and that this effect is blocked by CRF antagonist administration. KOR agonists stimulate the HPA axis in rodents and humans (Ur et al., 1997; Laorden et al., 2000), and it has previously been reported that KOR activation elicits CRF release (Nikolarakis et al., 1986; Song and Takemori, 1992) and vice-versa (Land et al., 2008). 
Studies in human cocaine abusers have also shown that stress increases the risk of drug abuse and relapse (De La Garza et al., 2009). The pharmacological or psychological activation of the hypothalamic pituitary adrenal axis has been shown to increase craving in addition to the probability of increased cocaine use (Elman et al., 2003; Shoptaw et al., 2004; Elman and Lukas, 2005). Sinha and colleagues have shown that stress imagery increases anxiety and craving for cocaine (Sinha et al., 1999, 2006; Fox et al., 2006). Importantly, this group has also shown that stress-induced cocaine craving is associated with a shorter time to relapse in cocaine-dependent subjects following discharge from inpatient treatment (Sinha et al., 2006). To date, the imaging studies in addiction have not focused on stressinduced reinstatement of cocaine-seeking behavior, and future research should focus on the role of dopamine and KOR signaling and stress.

Thus, DYN/KOR signaling appears to play a crucial role in reinstating drug-seeking behavior by mediating the negative effects associated with drug cessation and stress-induced drug taking (Koob and Le Moal, 2008; Muschamp and Carlezon, 2013).

\section{CONCLUSION}

The data presented here suggest that blunted striatal dopamine release measured with imaging in cocaine dependence may be associated with an upregulation of DYN. Acting at the KOR of the dopamine terminals, KOR activation would be expected to produce a decrease in striatal dopamine release. Post-mortem studies in cocaine abusers and animal studies show that both KOR and DYN are upregulated following chronic cocaine exposure, and that this effect is long lasting (Spangler et al., 1993, 1996). In

\section{REFERENCES}

Abi-Dargham, A., Simpson, N., Kegeles, L., Parsey, R., Hwang, D. R., Anjilvel, S., et al. (1999). PET studies of binding competition between endogenous dopamine and the D1 radiotracer [11C]NNC 756. Synapse 32,93-109. doi:10.1002/(SICI) 10982396(199905)32:2<93::AID-

SYN3>3.0.CO;2-C

Ackerman, J. M., and White, F. J. (1992). Decreased activity of rat A10 dopamine neurons following withdrawal from repeated cocaine. Eur. J. Pharmacol. 218, 171-173. doi:10.1016/0014-2999(92) 90161-V

Acri, J. B., Thompson, A. C., and Shippenberg, T. (2001). Modulation of pre- and post-synaptic dopamine D2 receptor function by the selective kappa-opioid receptor agonist U69593. Synapse 39 , 343-350. doi:10.1002/10982396(20010315)39:4<343::AIDSYN1018>3.0.CO;2-Q

Amato, L., Minozzi, S., Pani, P. P., Solimini, R., Vecchi, S., Zuccaro, P., et al. (2011). Dopamine agonists for the treatment of cocaine

addition, the imaging studies in cocaine abusers show that blunted dopamine release is associated with an increased risk of relapse while animal studies show that activation of the KOR increases cocaine self-administration. However, studies have not been conducted measuring KOR and striatal dopamine signaling in human cocaine abusers concurrently. Thus, future studies imaging the KOR in cocaine abusers and correlating their level directly with dopamine transmission, and with relevant clinical outcomes, is needed.

Chronic cocaine exposure induces CREB phosphorylation and changes in gene expression, which increase expression of prodynorphin mRNA in the nucleus accumbens in addition to other factors. As described above, excessive DYN signaling results in a decrease in extracellular dopamine release, which has been shown in the imaging studies of human cocaine abusers. These findings suggest that increasing signaling at the dopamine receptors may be an appropriate treatment approach, but clinical studies using dopamine agonists have not shown efficacy (Amato et al., 2011). Thus, pharmacologic manipulations that increase endogenous dopamine may be of use, particularly since imaging studies show that intact dopamine signaling is predictive of a positive treatment response. The data reviewed here suggest that KOR antagonists would be expected to counteract the effects of DYN upregulation and may restore pre-synaptic dopamine release. In addition, KOR antagonists have very limited, if any, nervous system side effects (Kreek et al., 2012) and block stress-induced cocaine self-administration in animal studies. Together, these findings suggest that KOR antagonists may provide an important avenue for future treatment development for cocaine addiction (Muschamp and Carlezon, 2013).

for incentive salience. Psychopharmacology (Berl.) 191, 391-431. doi:10.1007/s00213-006-0578-x

Bisaga, A., Aharonovich, E., Cheng, W. Y., Levin, F. R., Mariani, J. J., Raby, W. N., et al. (2010). A placebocontrolled trial of memantine for cocaine dependence with high-value voucher incentives during a prerandomization lead-in period. Drug Alcohol Depend. 111, 97-104. doi:10. 1016/j.drugalcdep.2010.04.006

Boileau, I., Payer, D., Houle, S., Behzadi, A., Rusjan, P. M., Tong, J., et al. (2012). Higher binding of the dopamine D3 receptor-preferring ligand [11C]-(+)-propylhexahydro-naphtho-oxazin in methamphetamine polydrug users: a positron emission tomography study. J. Neurosci. 32, 1353-1359. doi:10.1523/JNEUROSCI.437111.2012

Breier, A., Su, T. P., Saunders, R., Carson, R. E., Kolachana, B. S., Debartolomeis, A., et al. (1997). Schizophrenia is associated with elevated amphetamine-induced synaptic dopamine concentrations: evidence from a novel positron emission tomography method. Proc. Natl. Acad. Sci. U.S.A. 94, 2569-2574. doi:10.1073/pnas.94.6.2569

Brodie, M. S., and Dunwiddie, T. V. (1990). Cocaine effects in the ventral tegmental area: evidence for an indirect dopaminergic mechanism of action. Naunyn Schmiedebergs Arch. Pharmacol. 342, 660-665. doi:10.1007/BF00175709

Bruijnzeel, A. W. (2009). kappaOpioid receptor signaling and brain reward function. Brain Res. Rev. 62, 127-146. doi:10. 1016/j.brainresrev.2009.09.008

Busto, U. E., Redden, L., Mayberg, H., Kapur, S., Houle, S., and Zawertailo, L. A. (2009). Dopaminergic activity in depressed smokers: a positron emission tomography study. Synapse 63, 681-689. doi:10.1002/syn. 20646

Butelman, E. R., Yuferov, V., and Kreek, M. J. (2012). kappaOpioid receptor/dynorphin system: genetic and pharmacotherapeutic implications for addiction. Trends Neurosci. 35, 587-596. doi:10.1016/j.tins.2012.05.005 
Carey, A. N., Borozny, K., Aldrich, J. V., and McLaughlin, J. P. (2007). Reinstatement of cocaine place-conditioning prevented by the peptide kappa-opioid receptor antagonist arodyn. Eur. J. Pharmacol. 569, 84-89. doi:10.1016/j.ejphar.2007.05.007

Carlezon, W. A. Jr., Beguin, C., Dinieri, J. A., Baumann, M. H., Richards, M. R., Todtenkopf, M. S., et al. (2006). Depressive-like effects of the kappa-opioid receptor agonist salvinorin $\mathrm{A}$ on behavior and neurochemistry in rats. J. Pharmacol. Exp. Ther. 316, 440-447. doi:10.1124/jpet.105.092304

Carlezon, W. A. Jr., Thome, J., Olson, V. G., Lane-Ladd, S. B., Brodkin, E. S., Hiroi, N., et al. (1998). Regulation of cocaine reward by CREB. Science 282, 2272-2275. doi:10.1126/science.282.5397.2272

Carroll, I., Thomas, J. B., Dykstra, L. A., Granger, A. L., Allen, R. M., Howard, J. L., et al. (2004). Pharmacological properties of JDTic: a novel kappa-opioid receptor antagonist. Eur. J. Pharmacol. 501, 111-119. doi:10.1016/j.ejphar.2004.08.028

Castner, S. A., Al-Tikriti, M. S., Baldwin, R. M., Seibyl, J. P., Innis, R. B., and Goldman-Rakic, P. S. (2000). Behavioral changes and [123I]IBZM equilibrium SPECT measurement of amphetamine-induced dopamine release in rhesus monkeys exposed to subchronic amphetamine. Neuropsychopharmacology 22, 4-13. doi:10.1016/S0893-133X(99)000809

Chefer, V. I., Czyzyk, T., Bolan, E. A., Moron, J., Pintar, J. E., and Shippenberg, T. S. (2005). Endogenous kappa-opioid receptor systems regulate mesoaccumbal dopamine dynamics and vulnerability to cocaine. J. Neurosci. 25, 5029-5037. doi:10.1523/JNEUROSCI.085405.2005

Chen, Y., Chen, C., and Liu-Chen, L. Y. (2007). Dynorphin peptides differentially regulate the human kappa opioid receptor. Life Sci. 80, 1439-1448. doi:10.1016/j.lfs.2007.01.018

Chou, Y. H., Karlsson, P., Halldin, C., Olsson, H., and Farde, L. (1999). A PET study of D(1)-like dopamine receptor ligand binding during altered endogenous dopamine levels in the primate brain. Psychopharmacology (Berl.) 146, 220-227. doi:10.1007/s002130051110

Crain, S. M., and Shen, K. F. (1996). Modulatory effects of Gs-coupled excitatory opioid receptor functions on opioid analgesia, tolerance, and dependence. Neurochem. Res. 21, 1347-1351. doi:10.1007/BF02532375

Czoty, P. W., Morgan, D., Shannon, E. E., Gage, H. D., and Nader, M. A. (2004). Characterization of dopamine D1 and $\mathrm{D} 2$ receptor function in socially housed cynomolgus monkeys selfadministering cocaine. Psychopharmacology (Berl.) 174, 381-388. doi:10.1007/s00213-003-1752-z

Dalley, J. W., Everitt, B. J., and Robbins, T. W. (2011). Impulsivity, compulsivity, and top-down cognitive control. Neuron 69, 680-694. doi:10.1016/j.neuron.2011.01.020

Dalley, J. W., Fryer, T. D., Brichard, L., Robinson, E. S., Theobald, D. E., Laane, K., et al. (2007). Nucleus accumbens D2/3 receptors predict trait impulsivity and cocaine reinforcement. Science 315, 1267-1270. doi:10.1126/science.1137073

Daunais, J. B., and McGinty, J. F. (1995). Cocaine binges differentially alter striatal preprodynorphin and zif/268 mRNAs. Brain Res. Mol. Brain Res. 29, 201-210. doi:10.1016/0169328X(94)00246-B

Daunais, J. B., and McGinty, J. F. (1996). The effects of D1 or D2 dopamine receptor blockade on zif/268 and preprodynorphin gene expression in rat forebrain following a short-term cocaine binge. Brain Res. Mol. Brain Res. 35, 237-248. doi:10.1016/0169328X(95)00226-I

Daunais, J. B., Roberts, D. C., and McGinty, J. F. (1993). Cocaine self-administration increases preprodynorphin, but not c-fos, mRNA in rat striatum. Neuroreport 4, 543-546. doi:10.1097/00001756199305000-00020

Daunais, J. B., Roberts, D. C., and McGinty, J. F. (1995). Short-term cocaine self administration alters striatal gene expression. Brain Res. Bull.37, 523-527. doi:10.1016/03619230(95)00049-K

De La Garza, R. II, Ashbrook, L. H. Evans, S. E., Jacobsen, C. A., Kalechstein, A. D., and Newton, T. F. (2009). Influence of verbal recall of a recent stress experience on anxiety and desire for cocaine in non-treatment seeking, cocaine-addicted volunteers. Am. J. Addict. 18, 481-487. doi:10.3109/10550490903205876

Di Chiara, G., and Imperato, A. (1988). Opposite effects of mu and kappa opiate agonists on dopamine release in the nucleus accumbens and in the dorsal caudate of freely moving rats. J. Pharmacol. Exp. Ther. 244, 1067-1080.

Donzanti, B. A., Althaus, J. S., Payson, M. M., and Von Voigtlander, P. F. (1992).
Kappa agonist-induced reduction in dopamine release: site of action and tolerance. Res. Commun. Chem. Pathol. Pharmacol. 78, 193-210.

Drakenberg, K., Nikoshkov, A., Horvath, M. C., Fagergren, P., Gharibyan, A., Saarelainen, K., et al. (2006). Mu opioid receptor A118G polymorphism in association with striatal opioid neuropeptide gene expression in heroin abusers. Proc. Natl. Acad. Sci. U.S.A. 103, 7883-7888. doi:10.1073/pnas.0600871103

Drevets, W. C., Gautier, C., Price, J. C. Kupfer, D. J., Kinahan, P. E., Grace, A. A., et al. (2001). Amphetamineinduced dopamine release in human ventral striatum correlates with euphoria. Biol. Psychiatry 49, 81-96. doi:10.1016/S0006-3223(00)010386

Elman, I., and Lukas, S. E. (2005). Effects of cortisol and cocaine on plasma prolactin and growth hormone levels in cocaine-dependent volunteers. Addict. Behav. 30, 859-864. doi:10.1016/j.addbeh.2004.08.019

Elman, I., Lukas, S. E., Karlsgodt, K. H., Gasic, G. P., and Breiter, H. C. (2003). Acute cortisol administration triggers craving in individuals with cocaine dependence. Psychopharmacol. Bull. 37, 84-89.

Endoh, T., Matsuura, H., Tanaka, C., and Nagase, H. (1992). Norbinaltorphimine: a potent and selective kappa-opioid receptor antagonist with long-lasting activity in vivo. Arch. Int. Pharmacodyn. Ther. 316 30-42.

Endres, C. J., Kolachana, B. S., Saunders, R. C., Su, T., Weinberger, D., Breier A., et al. (1997). Kinetic modeling of [C-11]raclopride: combined PET-microdialysis studies. J. Cereb. Blood Flow Metab. 17, 932-942. doi:10.1097/00004647-19970900000002

Everitt, B. J., Belin, D., Economidou, D., Pelloux, Y., Dalley, J. W., and Robbins, T. W. (2008). Review. Neural mechanisms underlying the vulnerability to develop compulsive drug-seeking habits and addiction. Philos. Trans. R. Soc Lond. B Biol. Sci. 363, 3125-3135. doi:10.1098/rstb.2008.0089

Fagergren, P., Smith, H. R., Daunais, J. B., Nader, M. A., Porrino, L. J., and Hurd, Y. L. (2003). Temporal upregulation of prodynorphin mRNA in the primate striatum after cocaine self-administration. Eur. J. Neurosci. 17, 2212-2218. doi:10.1046/j.14609568.2003.02636.x

Ford, C. P., Mark, G. P., and Williams, J. T. (2006). Properties and opioid inhibition of mesolimbic dopamine neurons vary according to target location. J. Neurosci. 26, 2788-2797. doi:10.1523/JNEUROSCI.433105.2006

Fox, H. C., Garcia, M. Jr., Kemp, K., Milivojevic, V., Kreek, M. J., and Sinha, R. (2006). Gender differences in cardiovascular and corticoadrenal response to stress and drug cues in cocaine dependent individuals. Psychopharmacology (Berl.) 185, 348-357. doi:10.1007/s00213005-0303-1

Frankel, P. S., Alburges, M. E., Bush, L., Hanson, G. R., and Kish, S. J. (2007). Brain levels of neuropeptides in human chronic methamphetamine users. $\mathrm{Neu}$ ropharmacology 53, 447-454. doi:10. 1016/j.neuropharm.2007.06.009

Frankel, P. S., Alburges, M. E., Bush, L., Hanson, G. R., and Kish, S. J. (2008). Striatal and ventral pallidum dynorphin concentrations are markedly increased in human chronic cocaine users. Neuropharmacology 55, 41-46. doi:10. 1016/j.neuropharm.2008.04.019

Fuentealba, J. A., Gysling, K., Magendzo, K., and Andres, M. E. (2006). Repeated administration of the selective kappa-opioid receptor agonist U-69593 increases stimulated dopamine extracellular levels in the rat nucleus accumbens. J. Neurosci. Res. 84, 450-459. doi:10.1002/jnr.20890

Fusar-Poli, P., and Meyer-Lindenberg, A. (2013). Striatal presynaptic dopamine in schizophrenia, part I: meta-analysis of dopamine active transporter (DAT) density. Schizophr. Bull. 39, 22-32. doi:10.1093/schbul/sbr111

Gao, W. Y., Lee, T. H., King, G. R., and Ellinwood, E. H. (1998). Alterations in baseline activity and quinpirole sensitivity in putative dopamine neurons in the substantia nigra and ventral tegmental area after withdrawal from cocaine pretreatment. Neuropsychopharmacology 18, 222-232. doi:10.1016/S0893133X(97)00132-2

Gehrke, B. J., Chefer, V. I., and Shippenberg, T. S. (2008). Effects of acute and repeated administration of salvinorin A on dopamine function in the rat dorsal striatum. Psychopharmacology (Berl.) 197, 509-517. doi:10.1007/s00213007-1067-6

George, S. R., and O'Dowd, B. F. (2007). A novel dopamine receptor signaling unit in brain: heterooligomers of D1 and D2 dopamine receptors. ScientificWorldJournal 7, 58-63. doi:10.1100/tsw.2007.223 
Gerfen, C. R. (2000). Molecular effects of dopamine on striatal-projection pathways. Trends Neurosci. 23, S64-S70. doi:10.1016/S14711931(00)00019-7

Gerfen, C. R., and Surmeier, D. J. (2011). Modulation of striatal projection systems by dopamine. Annu. Rev. Neurosci. 34, 441-466. doi:10.1146/annurev-neuro061010-113641

Gerrits, M. A., Petromilli, P., Westenberg, H. G., Di Chiara, G., and Van Ree, J. M. (2002). Decrease in basal dopamine levels in the nucleus accumbens shell during daily drugseeking behaviour in rats. Brain Res. 924, 141-150. doi:10.1016/S00068993(01)03105-5

Girault, J. A. (2012). Signaling in striatal neurons: the phosphoproteins of reward, addiction, and dyskinesia. Prog. Mol. Biol. Transl. Sci. 106, 33-62. doi:10.1016/B978-0-12396456-4.00006-7

Gorelick, D. A., Kim, Y. K., Bencherif, B., Boyd, S. J., Nelson, R., Copersino, M. L., et al. (2008). Brain mu-opioid receptor binding: relationship to relapse to cocaine use after monitored abstinence. Psychopharmacology (Berl.) 200, 475-486. doi:10.1007/ s00213-008-1225-5

Groman, S. M., and Jentsch, J. D. (2012). Cognitive control and the dopamine $\mathrm{D}(2)$-like receptor: a dimensional understanding of addiction. Depress. Anxiety 29, 295-306. doi:10.1002/da. 20897

Gross, G., and Drescher, K. (2012). “The role of dopamine $\mathrm{D}(3)$ receptors in antipsychotic activity and cognitive functions," in Handbook of Experimental Pharmacology, eds M. Geyer and G. Gross (Heidelberg: Springer), 167-210.

Gross, R. A., Moises, H. C., Uhler, M. D., and Macdonald, R. L. (1990). Dynorphin A and cAMPdependent protein kinase independently regulate neuronal calcium currents. Proc. Natl. Acad. Sci. U.S.A. 87, 7025-7029. doi:10.1073/ pnas.87.18.7025

Grudt, T. J., and Williams, J. T. (1993). kappa-Opioid receptors also increase potassium conductance. Proc. Natl. Acad. Sci. U.S.A. 90, 11429-11432. doi:10.1073/pnas.90.23.11429

Haney, M., Collins, E. D., Ward, A. S., Foltin, R. W., and Fischman, M. W. (1999). Effect of a selective dopamine D1 agonist (ABT-431) on smoked cocaine self-administration in humans. Psychopharmacology
(Berl.) 143, 102-110. doi:10.1007/s002130050925

Haney, M., Ward, A. S., Foltin, R. W., and Fischman, M. W. (2001). Effects of ecopipam, a selective dopamine D1 antagonist, on smoked cocaine self-administration by humans. Psychopharmacology (Berl.) 155, 330-337. doi:10.1007/s002130100725

Heijna, M. H., Bakker, J. M., Hogenboom, F., Mulder, A. H., and Schoffelmeer, A. N. (1992). Opioid receptors and inhibition of dopaminesensitive adenylate cyclase in slices of rat brain regions receiving a dense dopaminergic input. Eur. J. Pharmacol. 229, 197-202. doi:10.1016/00142999(92)90555-I

Heijna, M. H., Padt, M., Hogenboom, F., Portoghese, P. S., Mulder, A. H., and Schoffelmeer, A. N. (1990). Opioid receptor-mediated inhibition of dopamine and acetylcholine release from slices of rat nucleus accumbens, olfactory tubercle and frontal cortex. Eur. J. Pharmacol. 181, 267-278. doi:10.1016/00142999(90)90088-N

Hurd, Y. L., and Herkenham, M. (1993). Molecular alterations in the neostriatum of human cocaine addicts. Synapse 13, 357-369. doi:10.1002/syn.890130408

Hurd, Y. L., and Herkenham, M. (1995). The human neostriatum shows compartmentalization of neuropeptide gene expression in dorsal and ventral regions: an in situ hybridization histochemical analysis. Neuroscience 64, 571-586. doi:10.1016/0306-4522(94)00417-4

Innis, R. B., Cunningham, V. J., Delforge, J., Fujita, M., Gjedde, A., Gunn, R. N., et al. (2007). Consensus nomenclature for in vivo imaging of reversibly binding radioligands. J. Cereb. Blood Flow Metab. 27, 1533-1539. doi:10.1038/sj.jcbfm.9600493

Iremonger, K. J., and Bains, J. S. (2009). Retrograde opioid signaling regulates glutamatergic transmission in the hypothalamus. J. Neurosci. 29, 7349-7358. doi:10.1523/JNEUROSCI.038109.2009

Izenwasser, S., Acri, J. B., Kunko, P. M., and Shippenberg, T. (1998). Repeated treatment with the selective kappa opioid agonist U-69593 produces a marked depletion of dopamine D2 receptors. Synapse 30, 275-283. doi:10.1002/(SICI)10982396(199811)30:3<275::AIDSYN5>3.0.CO;2-8

Jackisch, R., Hotz, H., Allgaier, C., and Hertting, G. (1994). Presynaptic opioid receptors on dopaminergic nerves in the rabbit caudate nucleus: coupling to pertussis toxin-sensitive G-proteins and interaction with D2 autoreceptors? Naunyn Schmiedebergs Arch. Pharmacol. 349, 250-258. doi:10.1007/BF00169291

Jenab, S., Festa, E. D., Russo, S. J., Wu, H. B., Inturrisi, C. E., and QuinonesJenab, V. (2003). MK-801 attenuates cocaine induction of c-fos and preprodynorphin mRNA levels in Fischer rats. Brain Res. Mol. Brain Res. 117, 237-239. doi:10.1016/S0169328X(03)00319-X

Jones, R. M., and Portoghese, P. S. (2000). 5'-Guanidinonaltrindole, a highly selective and potent kappaopioid receptor antagonist. Eur. J. Pharmacol. 396, 49-52. doi:10. 1016/S0014-2999(00)00208-9

Kirkland Henry, P., Davis, M., and Howell, L. L. (2009). Effects of cocaine self-administration history under limited and extended access conditions on in vivo striatal dopamine neurochemistry and acoustic startle in rhesus monkeys. Psychopharmacology (Berl.) 205, 237-247. doi:10.1007/s00213-009-1534-3

Knoll, A. T., Muschamp, J. W., Sillivan, S. E., Ferguson, D., Dietz, D. M., Meloni, E. G., et al. (2011). Kappa opioid receptor signaling in the basolateral amygdala regulates conditioned fear and anxiety in rats. Biol. Psychiatry 70, 425-433. doi:10.1016/j.biopsych.2011.03.017

Koob, G. F. (2013). Theoretical frameworks and mechanistic aspects of alcohol addiction: alcohol addiction as a reward deficit disorder. Curr. Top. Behav. Neurosci. 13, 3-30. doi:10.1007/7854_2011_129

Koob, G. F., Ahmed, S. H., Boutrel, B., Chen, S. A., Kenny, P. J., Markou, A., et al. (2004). Neurobiological mechanisms in the transition from drug use to drug dependence. Neurosci. Biobehav. Rev. 27, 739-749. doi:10.1016/j.neubiorev.2003.11.007

Koob, G. F., and Le Moal, M. (2008). Addiction and the brain antireward system. Annu. Rev. Psychol. 59, 29-53. doi:10.1146/ annurev.psych.59.103006.093548

Kreek, M. J., Levran, O., Reed, B., Schlussman, S. D., Zhou, Y., and Butelman, E. R. (2012). Opiate addiction and cocaine addiction: underlying molecular neurobiology and genetics. J. Clin. Invest. 122 , 3387-3393. doi:10.1172/JCI60390

Lacey, M. G., Mercuri, N. B., and North, R. A. (1990). Actions of cocaine on rat dopaminergic neurones in vitro. Br. J. Pharmacol. 99, 731-735. doi:10.1111/j.14765381.1990.tb12998.x
Lahti, R. A., Mickelson, M. M., McCall, J. M., and Von Voigtlander, P. F. (1985). [3H]U-69593 a highly selective ligand for the opioid kappa receptor. Eur. J. Pharmacol. 109, 281-284. doi:10.1016/0014-2999(85)90431-5

Land, B. B., Bruchas, M. R., Lemos, J. C., $\mathrm{Xu}, \mathrm{M} ., \mathrm{Melief}, \mathrm{E}$. J., and Chavkin, C. (2008). The dysphoric component of stress is encoded by activation of the dynorphin kappa-opioid system. J. Neurosci. 28, 407-414. doi:10.1523/JNEUROSCI.445807.2008

Laorden, M. L., Castells, M. T., Martinez, M. D., Martinez, P. J., and Milanes, M. V. (2000). Activation of c-fos expression in hypothalamic nuclei by muand kappa-receptor agonists: correlation with catecholaminergic activity in the hypothalamic paraventricular nucleus. Endocrinology 141, 1366-1376. doi:10.1210/en.141.4.1366

Laruelle, M. (2000). Imaging synaptic neurotransmission with in vivo binding competition techniques: a critical review. J. Cereb. Blood Flow Metab. 20, 423-451. doi:10.1097/00004647-20000300000001

Laruelle, M., Iyer, R. N., Al-Tikriti, M. S., Zea-Ponce, Y., Malison, R., Zoghbi, S. S., et al. (1997) Microdialysis and SPECT measurements of amphetamine-induced dopamine release in nonhuman primates. Synapse 25, 1-14. doi:10.1002/(SICI)10982396(199701)25:1<1::AID$\mathrm{SYN} 1>3.0 . \mathrm{CO} ; 2-\mathrm{H}$

Law, P. Y., Wong, Y. H., and Loh, H. H. (2000). Molecular mechanisms and regulation of opioid receptor signaling. Annu. Rev. Pharmacol. Toxicol. 40, 389-430. doi:10. 1146/annurev.pharmtox.40.1.389

Lee, T. H., Gao, W. Y., Davidson, C., and Ellinwood, E. H. (1999). Altered activity of midbrain dopamine neurons following 7-day withdrawal from chronic cocaine abuse is normalized by D2 receptor stimulation during the early withdrawal phase. Neuropsychopharmacology 21, 127-136. doi:10.1016/S0893133X(99)00011-1

Li, S. J., Sivam, S. P., McGinty, J. F., Jiang, H. K., Douglass, J., Calavetta, L., et al. (1988). Regulation of the metabolism of striatal dynorphin by the dopaminergic system. J. Pharmacol. Exp. Ther. 246, 403-408.

Little, K. Y., Kirkman, J. A., Carroll, F. I., Clark, T. B., and Duncan, G. E. (1993). Cocaine use 
increases [3H]WIN 35428 binding sites in human striatum. Brain Res. 628, 17-25. doi:10.1016/00068993(93)90932-D

Little, K. Y., Zhang, L., Desmond, T., Frey, K. A., Dalack, G. W., and Cassin, B. J. (1999). Striatal dopaminergic abnormalities in human cocaine users. Am. J. Psychiatry $156,238-245$.

Liu, F. C., and Graybiel, A. M. (1998). Dopamine and calcium signal interactions in the developing striatum: control by kinetics of CREB phosphorylation. Adv. Pharmacol. 42, 682-686. doi:10.1016/S10543589(08)60840-6

Lobo, M. K., Covington, H. E. III, Chaudhury, D., Friedman, A. K., Sun, H., Damez-Werno, D., et al. (2010). Cell type-specific loss of BDNF signaling mimics optogenetic control of cocaine reward. Science 330, 385-390. doi:10.1126/science.1188472

Maisonneuve, I. M., Archer, S., and Glick, S. D. (1994). U50,488, a kappa agonist, attenuates cocaineinduced increases in extracellular dopamine in the nucleus accumbens of rats. Neurosci. Lett. 181, 57-60. doi:10.1016/0304-3940(94)90559-2

Malison, R. T., Best, S. E., Van Dyck, C. H., McCance, E. F., Wallace, E. A., Laruelle, M., et al. (1998). Elevated striatal dopamine transporters during acute cocaine abstinence as measured by [123I] beta-CIT SPECT. Am. J. Psychiatry 155, 832-834.

Malison, R. T., Mechanic, K. Y., Klummp, H., Baldwin, R. M., Kosten, T. R., Seibyl, J. P., et al. (1999). Reduced amphetamine-stimulated dopamine release in cocaine addicts as measured by [123I]IBZM SPECT. J. Nucl. Med. 40, 110.

Margolis, E. B., Hjelmstad, G. O., Bonci, A., and Fields, H. L. (2003). Kappaopioid agonists directly inhibit midbrain dopaminergic neurons. J. Neurosci. 23, 9981-9986.

Margolis, E. B., Lock, H., Chefer, V. I., Shippenberg, T. S., Hjelmstad, G. O., and Fields, H. L. (2006). Kappa opioids selectively control dopaminergic neurons projecting to the prefrontal cortex. Proc. Natl. Acad. Sci. U.S.A. 103, 2938-2942. doi:10.1073/pnas.0511159103

Marinelli, M., Cooper, D. C., Baker, L. K., and White, F. J. (2003). Impulse activity of midbrain dopamine neurons modulates drug-seeking behavior. Psychopharmacology (Berl.) 168, 84-98. doi:10.1007/s00213-003-1491-1

Martinez, D., Broft, A., Foltin, R. W., Slifstein, M., Hwang, D. R., Huang,
Y., et al. (2004). Cocaine dependence and $\mathrm{d} 2$ receptor availability in the functional subdivisions of the striatum: relationship with cocaine-seeking behavior. Neuropsychopharmacology 29, 1190-1202. doi:10.1038/sj.npp.1300420

Martinez, D., Carpenter, K. M., Liu, F., Slifstein, M., Broft, A., Friedman, A. C., et al. (2011). Imaging dopamine transmission in cocaine dependence: link between neurochemistry and response to treatment. Am. J. Psychiatry 168, 634-641. doi:10.1176/appi.ajp.2010.10050748 Martinez, D., Greene, K., Broft, A., Kumar, D., Liu, F., Narendran, R., et al. (2009a). Lower level of endogenous dopamine in patients with cocaine dependence: findings from PET imaging of $\mathrm{D}(2) / \mathrm{D}(3)$ receptors following acute dopamine depletion. Am. J. Psychiatry 166, 1170-1177. doi:10.1176/appi.ajp.2009.08121801

Martinez, D., Slifstein, M., Narendran, R., Foltin, R. W., Broft, A., Hwang, D. R., et al. (2009b). Dopamine D1 receptors in cocaine dependence measured with PET and the choice to self-administer cocaine. Neuropsychopharmacology 34, 17741782. doi:10.1038/npp.2008.235

Martinez, D., Kim, J. H., Krystal, J., and Abi-Dargham, A. (2007a). Imaging the neurochemistry of alcohol and substance abuse. Neuroimaging Clin. N. Am. 17, 539-555. doi:10.1016/j.nic.2007.07.004

Martinez, D., Narendran, R., Foltin, R. W., Slifstein, M., Hwang, D. R., Broft, A., et al. (2007b). Amphetamine-induced dopamine release: markedly blunted in cocaine dependence and predictive of the choice to self-administer cocaine. Am. J. Psychiatry 164, 622-629. doi:10.1176/appi.ajp.164.4.622

Martinez, D., and Narendran, R. (2010). Imaging neurotransmitter release by drugs of abuse. Curr. Top. Behav. Neurosci. 3, 219-245. doi:10.1007/7854_2009_34

Martinez, D., Saccone, P. A., Liu, F., Slifstein, M., Orlowska, D., Grassetti, A., et al. (2012). Deficits in dopamine $\mathrm{D}(2)$ receptors and presynaptic dopamine in heroin dependence: commonalities and differences with other types of addiction. Biol. Psychiatry 71, 192-198. doi:10.1016/j.biopsych.2011.08.024

Martinez, D., Slifstein, M., Broft, A., Mawlawi, O., Hwang, D. R., Huang, Y., et al. (2003). Imaging human mesolimbic dopamine transmission with positron emission tomography. Part II: amphetamineinduced dopamine release in the functional subdivisions of the striatum. J. Cereb. Blood Flow Metab. 23, 285-300. doi:10.1097/00004647200303000-00004

Mash, D. C., and Staley, J. K. (1999). D3 dopamine and kappa opioid receptor alterations in human brain of cocaine-overdose victims. Ann. N. Y. Acad. Sci. 877, 507-522. doi:10.1111/j.17496632.1999.tb09286.x

Matuskey, D., Gallezot, J., Keunpoong, L., Zheng, M., Lin, S., Carson, R., et al. (2011). Subcortical D3/D2 receptor binding in cocaine dependent humans. J. Nucl. Med. 52, 1284.

McClung, C. A., and Nestler, E. J. (2008). Neuroplasticity mediated by altered gene expression. Neuropsychopharmacology 33, 3-17. doi:10.1038/sj.npp.1301544

McClung, C. A., Ulery, P. G., Perrotti, L. I., Zachariou, V., Berton, O., and Nestler, E. J. (2004). DeltaFosB: a molecular switch for long-term adaptation in the brain. Brain Res. Mol. Brain Res. 132, 146-154. doi:10. 1016/j.molbrainres.2004.05.014

McLaughlin, J. P., Land, B. B., Li, S., Pintar, J. E., and Chavkin, C. (2006). Prior activation of kappa opioid receptors by U50,488 mimics repeated forced swim stress to potentiate cocaine place preference conditioning. Neuropsychopharmacology 31, 787-794. doi:10.1038/sj.npp. 1300860

McLaughlin, J. P., Marton-Popovici, M., and Chavkin, C. (2003). Kappa opioid receptor antagonism and prodynorphin gene disruption block stress-induced behavioral responses. J. Neurosci. 23, 5674-5683.

Meador-Woodruff, J. H., Little, K. Y., Damask, S. P., Mansour, A., and Watson, S. J. (1993). Effects of cocaine on dopamine receptor gene expression: a study in the postmortem human brain. Biol. Psychiatry 34, 348-355. doi:10.1016/0006-3223(93)90178-G

Melis, M., Spiga, S., and Diana, M. (2005). The dopamine hypothesis of drug addiction: hypodopaminergic state. Int. Rev. Neurobiol. 63, 101-154. doi:10.1016/S00747742(05)63005-X

Morgan, D., Grant, K. A., Gage, H. D., Mach, R. H., Kaplan, J. R., Prioleau, O., et al. (2002). Social dominance in monkeys: dopamine D2 receptors and cocaine selfadministration. Nat. Neurosci. 5, 169-174. doi:10.1038/nn798

Mucha, R. F., and Herz, A. (1985). Motivational properties of kappa and mu opioid receptor agonists studied with place and taste preference conditioning.
Psychopharmacology (Berl.) 86, 274-280. doi:10.1007/BF00432213

Munro, C. A., McCaul, M. E., Wong, D. F., Oswald, L. M., Zhou, Y., Brasic, J., et al. (2006). Sex differences in striatal dopamine release in healthy adults. Biol. Psychiatry 59, 966-974. doi:10.1016/j.biopsych.2006.01.008

Muschamp, J. W., and Carlezon, W. A. Jr. (2013). Roles of nucleus accumbens CREB and dynorphin in dysregulation of motivation. Cold Spring Harb. Perspect. Med. doi:10.1101/cshperspect.a012005. [Epub ahead of print].

Nader, M. A., Morgan, D., Gage, H. D., Nader, S. H., Calhoun, T. L., Buchheimer, N., et al. (2006). PET imaging of dopamine D2 receptors during chronic cocaine self-administration in monkeys. Nat. Neurosci. 9, 1050-1056. doi:10.1038/nn1737

Narendran, R., Lopresti, B. J., Martinez, D., Mason, N. S., Himes, M., May, M. A., et al. (2012). In vivo evidence for low striatal vesicular monoamine transporter 2 (VMAT2) availability in cocaine abusers. Am. J. Psychiatry 169, 55-63. doi:10.1176/appi.ajp.2011.11010126

Nikolarakis, K. E., Almeida, O. F., and Herz, A. (1986). Stimulation of hypothalamic beta-endorphin and dynorphin release by corticotropinreleasing factor (in vitro). Brain Res. 399, 152-155. doi:10.1016/00068993(86)90610-4

Oliveto, A., Poling, J., Mancino, M. J., Williams, D. K., Thostenson, J., Pruzinsky, R., et al. (2012). Sertraline delays relapse in recently abstinent cocaine-dependent patients with depressive symptoms. Addiction 107, 131-141. doi:10.1111/j.13600443.2011.03552.x

Parsons, L. H., Smith, A. D., and Justice, J. B. Jr. (1991). Basal extracellular dopamine is decreased in the rat nucleus accumbens during abstinence from chronic cocaine. Synapse 9, 60-65. doi:10.1002/syn.890090109

Pascoli, V., Turiault, M., and Luscher, C. (2012). Reversal of cocaineevoked synaptic potentiation resets drug-induced adaptive behaviour. Nature 481, 71-75. doi:10.1038/nature10709

Pfeiffer, A., Brantl, V., Herz, A., and Emrich, H. M. (1986) Psychotomimesis mediated by kappa opiate receptors. Science 233, 774-776. doi:10.1126/science.3016896

Redila, V. A., and Chavkin, C. (2008). Stress-induced reinstatement of cocaine seeking is 
mediated by the kappa opioid system. Psychopharmacology (Berl.) 200, 59-70. doi:10. 1007/s00213-008-1122-y

Robertson, M. W., Leslie, C. A., and Bennett, J. P. Jr. (1991). Apparent synaptic dopamine deficiency induced by withdrawal from chronic cocaine treatment. Brain Res. 538, 337-339. doi:10.1016/0006-8993(91)90451-Z

Rossetti, Z. L., Melis, F., Carboni, S., and Gessa, G. L. (1992). Dramatic depletion of mesolimbic extracellular dopamine after withdrawal from morphine, alcohol or cocaine: a common neurochemical substrate for drug dependence. Ann. N. Y. Acad. Sci. 654, 513-516. doi:10.1111/j.17496632.1992.tb26016.x

Roth, B. L., Baner, K., Westkaemper, R., Siebert, D., Rice, K. C., Steinberg, S., et al. (2002). Salvinorin A: a potent naturally occurring nonnitrogenous kappa opioid selective agonist. Proc. Natl. Acad. Sci. U.S.A. 99, 11934-11939. doi:10.1073/pnas.182234399

Salamone, J. D., and Correa, M. (2012). The mysterious motivational functions of mesolimbic dopamine. Neuron 76, 470-485. doi:10.1016/j.neuron.2012.10.021

Schlussman, S. D., Zhang, Y., Yuferov, V., Laforge, K. S., Ho, A., and Kreek, M. J. (2003). Acute 'binge' cocaine administration elevates dynorphin mRNA in the caudate putamen of C57BL/6J but not 129/J mice. Brain Res. 974, 249-253. doi:10. 1016/S0006-8993(03)02561-7

Schlussman, S. D., Zhou, Y., Bailey, A., Ho, A., and Kreek, M. J. (2005). Steady-dose and escalatingdose "binge" administration of cocaine alter expression of behavioral stereotypy and striatal preprodynorphin mRNA levels in rats. Brain Res. Bull. 67, 169-175. doi:10. 1016/j.brainresbull.2005.04.018

Schultz, W. (2006). Behavioral theories and the neurophysiology of reward. Annu. Rev. Psychol. 57, 87-115. doi:10.1146/annurev.psych.56.0911 03.070229

Shippenberg, T. S., Zapata, A., and Chefer, V. I. (2007). Dynorphin and the pathophysiology of drug addiction. Pharmacol. Ther. 116, 306-321. doi:10.1016/j.pharmthera.2007. 06.011

Shirayama, Y., Ishida, H., Iwata, M., Hazama, G. I., Kawahara, R., and Duman, R. S. (2004). Stress increases dynorphin immunoreactivity in limbic brain regions and dynorphin antagonism produces antidepressant-like effects. J. Neurochem. 90, 1258-1268. doi:10.1111/j.14714159.2004.02589.x

Shoptaw, S., Majewska, M. D., Wilkins, J., Twitchell, G., Yang, X., and Ling, W. (2004). Participants receiving dehydroepiandrosterone during treatment for cocaine dependence show high rates of cocaine use in a placebo-controlled pilot study. Exp. Clin. Psychopharmacol. 12, 126-135. doi:10.1037/1064-1297.12.2.126

Sinha, R., Catapano, D., and O'Malley, S. (1999). Stress-induced craving and stress response in cocaine dependent individuals. Psychopharmacology (Berl.) 142, 343-351. doi:10.1007/s002130050898

Sinha, R., Garcia, M., Paliwal, P., Kreek, M. J., and Rounsaville, B. J. (2006). Stress-induced cocaine craving and hypothalamic-pituitaryadrenal responses are predictive of cocaine relapse outcomes. Arch. Gen. Psychiatry 63, 324-331. doi:10.1001/archpsyc.63.3.324

Sivam, S. P. (1989). Cocaine selectively increases striatonigral dynorphin levels by a dopaminergic mechanism. J. Pharmacol. Exp. Ther. 250, 818-824.

Sivam, S. P. (1996). Dopaminergic regulation of striatonigral tachykinin and dynorphin gene expression: a study with the dopamine uptake inhibitor GBR-12909. Brain Res. Mol. Brain Res. 35, 197-210. doi:10.1016/0169328X(95)00216-F

Smiley, P. L., Johnson, M., Bush, L., Gibb, J. W., and Hanson, G. R. (1990). Effects of cocaine on extrapyramidal and limbic dynorphin systems. J. Pharmacol. Exp. Ther. 253, 938-943.

Sokoloff, P., Diaz, J., Le Foll, B., Guillin, O., Leriche, L., Bezard, E., et al. (2006). The dopamine D3 receptor: a therapeutic target for the treatment of neuropsychiatric disorders. CNS Neurol. Disord. Drug Targets 5, 25-43.

Song, Z. H., and Takemori, A. E. (1992). Stimulation by corticotropinreleasing factor of the release of immunoreactive dynorphin A from mouse spinal cords in vitro. Eur. J. Pharmacol. 222, 27-32. doi:10.1016/0014-2999(92)90458-G Spanagel, R., Herz, A., and Shippenberg, T. (1992). Opposing tonically active endogenous opioid systems modulate the mesolimbic dopaminergic pathway. Proc. Natl. Acad. Sci. U.S.A. 89, 2046-2050. doi:10.1073/pnas.89.6.2046

Spanagel, R., Herz, A., and Shippenberg, T. S. (1990). The effects of opioid peptides on dopamine release in the nucleus accumbens: an in vivo microdialysis study. J. Neurochem. 55, 1734-1740. doi:10.1111/j.14714159.1990.tb04963.x

Spangler, R., Ho, A., Zhou, Y., Maggos, C. E., Yuferov, V., and Kreek, M. J. (1996). Regulation of kappa opioid receptor mRNA in the rat brain by "binge" pattern cocaine administration and correlation with preprodynorphin mRNA. Brain Res. Mol. Brain Res. 38, 71-76. doi:10. 1016/0169-328X(95)00319-N

Spangler, R., Unterwald, E., and Kreek, M. (1993). Binge cocaine administration induces a sustained increase of prodynorphin mRNA in rat caudate-putamen. Brain Res. Mol. Brain Res. 19, 323-327. doi:10. 1016/0169-328X(93)90133-A

Staley, J. K., Rothman, R. B., Rice, K. C., Partilla, J., and Mash, D. C. (1997). Kappa2 opioid receptors in limbic areas of the human brain are upregulated by cocaine in fatal overdose victims. J. Neurosci. 17, 8225-8233.

Svingos, A., Chavkin, C., Colago, E. and Pickel, V. (2001). Major coexpression of k-opioid receptors and the dopamine transporter in nucleus accumbens axonal profiles. Synapse 42, 185-192. doi:10.1002/syn. 10005

Tang, A. H., and Collins, R. J. (1985). Behavioral effects of a novel kappa opioid analgesic, U-50488, in rats and rhesus monkeys. Psychopharmacology (Berl.) 85, 309-314. doi:10.1007/ BF00428193

Tejeda, H. A., Shippenberg, T. S., and Henriksson, R. (2012). The dynorphin/kappa-opioid receptor system and its role in psychiatric disorders. Cell. Mol. Life Sci. 69, 857-896. doi:10.1007/s00018-011-0844-x

Thompson, A., Zapata, A., Justice, J., Vaughan, R., Sharpe, L., and Shippenberg, T. (2000). Kappaopioid receptor activation modifies dopamine uptake in the nucleus accumbens and opposes the effects of cocaine. J. Neurosci. 20, 9333-9340.

Ur, E., Wright, D. M., Bouloux, P. M., and Grossman, A. (1997). The effects of spiradoline (U-62066E), a kappa-opioid receptor agonist, on neuroendocrine function in man. Br. J. Pharmacol. 120, 781-784. doi:10.1038/sj.bjp.0700971

Valdez, G. R., Platt, D. M., Rowlett, J. K., Ruedi-Bettschen, D., and Spealman, R. D. (2007). Kappa agonist-induced reinstatement of cocaine seeking in squirrel monkeys: a role for opioid and stress-related mechanisms. J. Pharmacol. Exp. Ther. 323, 525-533. doi:10.1124/jpet.107.125484
Valjent, E., Bertran-Gonzalez, J., Herve, D., Fisone, G., and Girault, J. A. (2009). Looking BAC at striatal signaling: cell-specific analysis in new transgenic mice. Trends Neurosci. 32, 538-547. doi:10.1016/j.tins.2009.06.005

Van Bockstaele, E. J., Gracy, K. N., and Pickel, V. M. (1995). Dynorphinimmunoreactive neurons in the rat nucleus accumbens: ultrastructure and synaptic input from terminals containing substance $\mathrm{P}$ and/or dynorphin. $J$. Comp. Neurol. 351, 117-133. doi:10.1002/cne.903510111

Volkow, N. D., Fowler, J. S., Wang, G. J., Hitzemann, R., Logan, J., Schlyer, D. J., et al. (1993). Decreased dopamine D2 receptor availability is associated with reduced frontal metabolism in cocaine abusers. Synapse 14, 169-177. doi:10.1002/syn.890140210

Volkow, N. D., Fowler, J. S., Wolf, A. P., Schlyer, D., Shiue, C. Y., Alpert, R., et al. (1990). Effects of chronic cocaine abuse on postsynaptic dopamine receptors. Am. J. Psychiatry 147, 719-724.

Volkow, N. D., Wang, G. J., Fowler, J. S., Hitzemann, R., Angrist, B., Gatley, S. J., et al. (1999). Association of methylphenidate-induced craving with changes in right striatoorbitofrontal metabolism in cocaine abusers: implications in addiction. Am. J. Psychiatry 156, 19-26.

Volkow, N. D., Wang, G. J., Fowler, J. S., Logan, J., Gatley, S. J., Hitzemann, R., et al. (1997). Decreased striatal dopaminergic responsiveness in detoxified cocaine-dependent subjects. Nature 386, 830-833. doi:10.1038/386830a0

Volkow, N. D., Wang, G. J., Fowler, J. S., Logan, J., Hitzemann, R., Ding, Y. S., et al. (1996). Decreases in dopamine receptors but not in dopamine transporters in alcoholics. Alcohol. Clin. Exp. Res. 20, 1594-1598.

Volkow, N. D., Wang, G.-J., Fowler, J. S., Logan, J., Schlyer, D., Hitzemann, R., et al. (1994). Imaging endogenous dopamine competition with $\left[{ }^{11} \mathrm{C}\right]$ raclopride in the human brain. Synapse 16, 255-262. doi:10.1002/syn.890160402

Von Voigtlander, P. F., and Lewis, R. A. (1982). U-50,488, a selective kappa opioid agonist: comparison to other reputed kappa agonists. Prog. Neuropsychopharmacol. Biol. Psychiatry 6, 467-470. doi:10.1016/S02785846(82)80130-9

Wadenberg, M. L. (2003). A review of the properties of spiradoline: a potent and selective kappa-opioid 
receptor agonist. CNS Drug Rev. 9, 187-198. doi:10.1111/j.15273458.2003.tb00248.x

Walsh, S. L., Geter-Douglas, B., Strain, E. C., and Bigelow, G. E. (2001). Enadoline and butorphanol: evaluation of kappa-agonists on cocaine pharmacodynamics and cocaine self-administration in humans. J. Pharmacol. Exp. Ther. 299, 147-158.

Walters, C. L., and Blendy, J. A. (2001). Different requirements for cAMP response element binding protein in positive and negative reinforcing properties of drugs of abuse. $J$. Neurosci. 21, 9438-9444.

Wang, G. J., Smith, L., Volkow, N. D., Telang, F., Logan, J., Tomasi, D., et al. (2012). Decreased dopamine activity predicts relapse in methamphetamine abusers. Mol. Psychiatry 17, 918-925. doi:10.1038/mp.2011.86

Wang, G. J., Volkow, N. D., Fowler, J. S., Fischman, M., Foltin, R., Abumrad, N. N., et al. (1997). Cocaine abusers do not show loss of dopamine transporters with age. Life Sci. 61, 1059-1065. doi:10.1016/S00243205(97)00614-0

Wee, S., and Koob, G. F. (2010). The role of the dynorphin-kappa opioid system in the reinforcing effects of drugs of abuse. Psychopharmacology (Berl.) 210, 121-135. doi:10.1007/s00213-010-1825-8

Wee, S., Orio, L., Ghirmai, S., Cashman, J. R., and Koob, G. F. (2009). Inhibition of kappa opioid receptors attenuated increased cocaine intake in rats with extended access to cocaine. Psychopharmacology (Berl.) 205, 565-575. doi:10.1007/s00213009-1563-y
Weiss, F., Paulus, M. P., Lorang, M. T., and Koob, G. F. (1992). Increases in extracellular dopamine in the nucleus accumbens by cocaine are inversely related to basal levels: effects of acute and repeated administration. J. Neurosci. 12, 4372-4380.

Wise, R. A. (2008). Dopamine and reward: the anhedonia hypothesis 30 years on. Neurotox. Res. 14, 169-183. doi:10.1007/BF03033808

Wu, J. C., Bell, K., Najafi, A., Widmark, C., Keator, D., Tang, C., et al. (1997). Decreasing striatal 6-FDOPA uptake with increasing duration of cocaine withdrawal. Neuropsychopharmacology 17, 402-409. doi:10.1016/S0893133X(97)00089-4

Xi, Z. X., Fuller, S. A., and Stein, E. A. (1998). Dopamine release in the nucleus accumbens during heroin self-administration is modulated by kappa opioid receptors: an in vivo fast-cyclic voltammetry study. J. Pharmacol. Exp. Ther. 284, 151-161.

Yokoo, H., Yamada, S., Yoshida, M., Tanaka, M., and Nishi, S. (1992). Attenuation of the inhibitory effect of dynorphin on dopamine release in the rat nucleus accumbens by repeated treatment with methamphetamine. Eur. J. Pharmacol. 222, 43-47. doi:10.1016/0014-2999(92)90461-C

You, Z. B., Herrera-Marschitz, M., and Terenius, L. (1999). Modulation of neurotransmitter release in the basal ganglia of the rat brain by dynorphin peptides. J. Pharmacol. Exp. Ther. 290, 1307-1315.

Yuferov, V., Zhou, Y., Laforge, K. S. Spangler, R., Ho, A., and Kreek, M. J.
(2001). Elevation of guinea pig brain preprodynorphin mRNA expression and hypothalamic-pituitary-adrenal axis activity by "binge" pattern cocaine administration. Brain Res. Bull. 55, 65-70. doi:10.1016/S03619230(01)00496-8

Zhang, Y., Butelman, E. R., Schlussman, S. D., Ho, A., and Kreek, M. J. (2004a). Effect of the endogenous kappa opioid agonist dynorphin $\mathrm{A}(1-17)$ on cocaine-evoked increases in striatal dopamine levels and cocaine-induced place preference in $\mathrm{C} 57 \mathrm{BL} / 6 \mathrm{~J}$ mice. Psychopharmacology (Berl.) 172, 422-429. doi:10.1007/ s00213-003-1688-3

Zhang, Y., Butelman, E. R., Schlussman, S. D., Ho, A., and Kreek, M. J. (2004b). Effect of the kappa opioid agonist R- 84760 on cocaine-induced increases in striatal dopamine levels and cocaine-induced place preference in C57BL/6J mice. Psychopharmacology (Berl.) 173, 146-152. doi:10.1007/s00213-003-1716-3

Zhang, Y., Schlussman, S. D., Rabkin, J., Butelman, E. R., Ho, A., and Kreek, M. J. (2013). Chronic escalating cocaine exposure, abstinence/withdrawal, and chronic re-exposure: effects on striatal dopamine and opioid systems in C57BL/6J mice. Neurophar macology 67, 259-266. doi:10. 1016/j.neuropharm.2012.10.015

Zhou, Y., Spangler, R., Schlussman, S. D., Yuferov, V. P., Sora, I., Ho, A., et al. (2002). Effects of acute "binge" cocaine on preprodynorphin, preproenkephalin, proopiomelanocortin, and corticotropinreleasing hormone receptor
mRNA levels in the striatum and hypothalamic-pituitary-adrenal axis of mu-opioid receptor knockout mice. Synapse 45, 220-229. doi:10.1002/syn.10101

Zubieta, J. K., Gorelick, D. A., Stauffer, R., Ravert, H. T., Dannals, R. F., and Frost, J. J. (1996). Increased mu opioid receptor binding detected by PET in cocaine-dependent men is associated with cocaine craving. Nat. Med. 2, 1225-1229. doi:10.1038/nm1196-1225

Conflict of Interest Statement: The authors declare that the research was conducted in the absence of any commercial or financial relationships that could be construed as a potential conflict of interest.

Received: 17 March 2013; accepted: 14 May 2013; published online: 03 June 2013.

Citation: Trifilieff $P$ and Martinez D (2013) Kappa-opioid receptor signaling in the striatum as a potential modulator of dopamine transmission in cocaine dependence. Front. Psychiatry 4:44. doi: 10.3389/fpsyt.2013.00044

This article was submitted to Frontiers in Addictive Disorders and Behavioral Dyscontrol, a specialty of Frontiers in Psychiatry.

Copyright () 2013 Trifilieffand Martinez. This is an open-access article distributed under the terms of the Creative Commons Attribution License, which permits use, distribution and reproduction in other forums, provided the original authors and source are credited and subject to any copyright notices concerning any third-party graphics etc. 